\title{
RISK OF BREAST CANCER DEVELOPMENT IN THE WOMEN OF THE YOUNGER AGE CATEGORIES IN UKRAIIE
}

\author{
Fedorenko Z., Hulak L., Ryzhov A., Horokh Ye., Sumkina O., Kutsenko L.
}

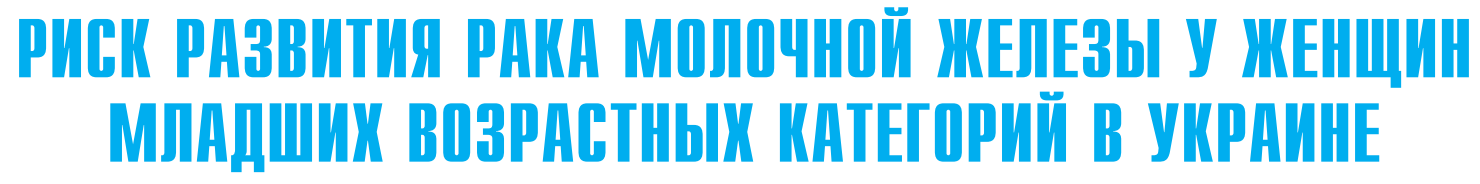

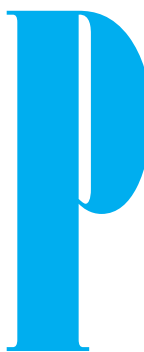

ФЕДОРЕНКО З.П. ГУЛАКЛ.О., ГОРОХ Е.Л., РЫЖОВ А.Ю. СУМКИНА Е.В., КУЦЕНКО Л.Б.

Национальный институт рака, г. Киев

УДК 616-006-058 (477) $+312.2$

Ключевые слова Национальный канцеррегистр Украины, заболеваемость злокачественными новообразованиями, эпидемиология рака молочной железы.

ак молочной железы (РМЖ) на протяжении последних десятилетий остается важнейшей медико-биологической и социально-экономической проблемой здравоохранения Украины, актуальность которой возрастает в связи с радиационным загрязнением обширных территорий Украины вследствие аварии на Чернобыльской АЭС.

Заболеваемость РМЖ имеет стабильный прирост во всех возрастных группах женской популяции Украины. Ежегодно регистрируется свыше 17,7 тысяч новых случаев болезни, а на учете онкологических учреждений состоят 163,3 тысяч больных.

В течение последних 25 лет РМЖ занимает первое место в структуре онкологической заболеваемости женщин Украины. По уточненным данным Национального канцер-регистра, в 2013 году удельный вес этой патологии составил 22,2\%. При изучении повозрастных особенностей заболеваемости раком

РИЗИК РОЗВИТКУ РАКУ МОЛОЧНОЇ ЗАЛОЗИ У ЖІНОК МОЛОДШИХ ВІКОВИХ КАТЕГОРІЙ В УКРАЇНІ

Федоренко 3.П., Гулак Л.О., Рижов А.Ю., Горох Є.Л., Сумкина О.В., Куценко Л.Б.

Національний інститут раку, м. Київ

Вивчення захворюваності на РМЖ населення України

і територій, підданих впливу Чорнобильської аварії, показало стабільне зростання показників, темпи приросту яких на контамінованих територіях були вдвічі вищими, ніж в Україні. Окремо вивчено особливості ураження РМЖ жіночого населення вікової групи 0-39 років як найбільш чутливої до радіаційного впливу. Встановлено, що РМЖ стабільно посідає перше місце у структурі захворюваності жіночого населення і в Україні, і у досліджуваних областях (20-24\%). Тобто у кожної п'ятої жінки, що захворіла на рак, діагностується РМЖ, що підкреслює значимість проблеми. Вивчення трендовых моделей РМЖ у жінок вікової категорії 0-39 років показало, що у післяаварійний період приріст показника захворюваності у контамінованих областях досяг 43,5\%, у той час як в Україні не перевищував 18,1\%. Ці особливості динаміки захворюваності на РМЖ сприяли істотному зближенню показників, зареєстрованих в Україні та областях радіаційного контролю, а з 1994-1997 років рівень захворюваності на РМЖ у більшості контамінованих областей перевищував середньоукраїнський.

Ключові слова: Національний канцер-регістр України, захворюваність на злоякісні новоутворення, епідеміологія раку молочної залози.

() Федоренко З.П., Гулак Л.О., Рижов А.Ю., Горох Є.Л., Сумкина О.В., Куценко Л.Б. СТАТТЯ, 2016. установлено, что уже в возрастной группе 18-29 лет ЗН молочной железы попадают в пятерку наиболее распространенных нозологических форм рака, в последующих возрастных группах (30-74 года) находятся на первом месте, а после 75 лет - на втором [1].

Интерес к данной патологии после аварии на ЧАЭС обусловлен тем, что в генезе РМЖ радиационный фактор может играть существенную роль [2, 3]. Нами в сотрудничестве с Гу "Национальный научный центр радиационной медицины НАМН Украины" было проведено исследование по изучению изменений в заболеваемости РМЖ населения Украины после Чернобыльской аварии в связи с возможным канцерогенным влиянием ионизирующей радиации. Полученные результаты показали, что статистически достоверная зависимость возникновения радиоиндуцированных опухолей молочной железы зарегистрирована лишь в когорте участниц ликвидации последствий аварии на ЧАЭС в 1986-1987 годах [412]. Однако рядом исследователей медицинских последствий атомной бомбардировки Хиросимы и Нагасаки установлено, что развитие РМЖ зависело от возраста женщин в момент бомбардировки. При этом наиболее часто опухоли возникали у лиц, облученных в возрасте от 5 до 20 лет, а средний латентный период развития опухоли составлял 18 лет $[13,14]$. Было также установлено, что показатель относительного риска развития РМЖ у лиц, облученных в возрасте 1029 лет, был выше, чем у женщин старше 30 лет.

Исходя из приведенных материалов, целью исследования стало изучение изменений структуры заболеваемости ЗН в динамике у лиц возрастной категории 0-39 лет в Украине и контаминированных вследствие аварии на ЧАЭС областях.

Материалы и методы. Изуче- 
ние заболеваемости РМЖ проводилось на основании персонифицированной информации Национального канцер-регистра Украины за 1996-2013 годы и ретроспективных данных МЗ Украины о заболеваемости в 1970-1995 годах (всего 453,6 тысяч случаев), в том числе в Житомирской, Киевской, Черниговской областях, относящихся к числу наиболее пострадавших от последствий аварии на ЧАЭС (20,5 тысяч случаев).

Для предотвращения влияния на результаты исследования погрешностей в учете использовался метод усреднения показателей за интервалы времени: 1970-1973; 19741977; 1978-1981; 1982-1985; 1986-1989; 1990-1993; 19941997; 1998-2001; 2002-2005; 2006-2009; 2010-2013 гг. Вычислялись грубые и стандартизированные по мировому стандарту населения показатели заболеваемости женщин, а также повозрастные показатели. Для оценки значимости временных трендов в динамических рядах показателей заболеваемости РМЖ использовался программный продукт "Joinpoint Regression Program", Версия 4.1.1.4-2015 [15].

Результаты исследования. Анализ динамических моделей заболеваемости РМЖ показал, что за 43 года стандартизированный показатель увеличился в 2 раза - от 21,1 до 42,8 на 100 тыс. населения $(\% / 0000)$, a среднегодовой прирост показателя составил 2,8\% (табл. 1). Наиболее интенсивным был темп прироста показателя в Житомирской области - 6,2\% ежегодно, несколько ниже в Киевской - 5,6\% и в Черниговской $-5,3 \%$, где уровни заболеваемости до аварии были существенно ниже, чем в Украине в целом.

При изучении динамики повозрастной заболеваемости РМЖ в 1976, 1986, 1996 и 2013 годах было установлено, что во всех возрастных категориях произошло увеличение показателей и в Украине, и в контаминированных областях (рис. 1). В 2013 году наибольший прирост данного показателя зарегистрирован для возрастной группы 60-69 лет, т.е. у женщин, которые на момент аварии на ЧАЭС относи-

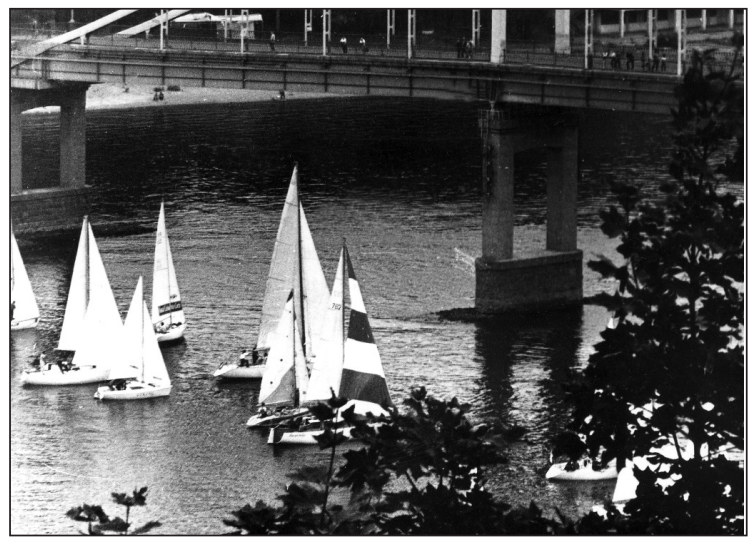

ФАКТОРИ ДОВКІЛля І ЗДОРОВ'я 트

лись к возрастной категории 33-42 года.

Исследование особенностей развития онкоэпидемиологического процесса в возрастной группе 0-39 лет начато с изучения изменений в структуре ее заболеваемости злокачественными новообразованиями (ЗН) как в Украине в целом, так и в контаминированных областях (рис. 2).

Установлено, что РМЖ занимает ведущее место в структуре заболеваемости ЗН во всех исследуемых временных периодах. При этом в 1974-1979 годах удельный вес РМЖ в структуре заболеваемости ЗН в Украине составлял 21,0\%, в последующем возрос до 23,0\%, а в 20102013 годах снизился до 20,0\% на фоне резкого возрастания удельного веса рака щитовидной железы и шейки матки. В контаминированных областях в 1986-1989 годах удельный вес РМЖ незначительно снизился (от 24,0\% до

Таблица 1

Динамика заболеваемости РМЖ женского населения Украины и контаминированных областей (1976-2013)

\begin{tabular}{|l|c|c|c|c|c|c|}
\hline \multirow{2}{*}{$\begin{array}{c}\text { Административная } \\
\text { территория }\end{array}$} & $\begin{array}{c}\text { Показатель заболеваемости } \\
\text { на 100 тыс. женского } \\
\text { населения (мировой } \\
\text { стандарт населения) }\end{array}$ & \multicolumn{2}{|c|}{$\begin{array}{c}\text { Абсолютный прирост } \\
\text { заболеваемелести, \% }\end{array}$} \\
\cline { 2 - 7 } & 1976 г. & 1986 г. & 2013 г. & $\begin{array}{c}1976- \\
1986\end{array}$ & $\begin{array}{c}1986- \\
2013\end{array}$ & $\begin{array}{c}\text { Средне- } \\
\text { годовой }\end{array}$ \\
\hline Украина & 21,1 & 30,1 & 42,8 & 42,7 & 42,2 & 2,9 \\
\hline Житомирская обл. & 17,3 & 18,9 & 57,1 & 9,2 & 202,1 & 6,6 \\
\hline Киевская обл. & 20,8 & 28,4 & 63,8 & 36,5 & 124,6 & 5,9 \\
\hline Черниговская обл. & 17,3 & 22,1 & 51,5 & 27,7 & 133,0 & 5,6 \\
\hline
\end{tabular}

Таблица 2

Динамика показателей заболеваемости РМЖ в возрастной группе 0-39 лет

\begin{tabular}{|c|c|c|c|c|c|c|c|c|}
\hline \multirow{3}{*}{ Годы } & \multicolumn{8}{|c|}{ Административная территория (область) } \\
\hline & \multicolumn{2}{|c|}{ Житомирская } & \multicolumn{2}{|c|}{ Киевская } & \multicolumn{2}{|c|}{ Черниговская } & \multicolumn{2}{|c|}{ Украина } \\
\hline & $0 / 0000$ & $\begin{array}{c}\text { при- } \\
\text { рост, \% }\end{array}$ & $\% / 0000$ & $\begin{array}{c}\text { при- } \\
\text { рост, \% }\end{array}$ & $\% / 0000$ & \begin{tabular}{|c|} 
при- \\
рост, \%
\end{tabular} & $0 / 0000$ & $\begin{array}{c}\text { при- } \\
\text { рост,\% }\end{array}$ \\
\hline $1970-1973$ & 3,58 & -- & 3,77 & -- & 4,67 & 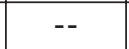 & 4,49 & -- \\
\hline 1974-1977 & 3,77 & 5,4 & 6,31 & 67,2 & 5,25 & 12,6 & 5,45 & 21,3 \\
\hline 1978-1981 & 3,38 & $-10,4$ & 7,24 & 14,9 & 4,69 & $-10,8$ & 5,52 & 1,3 \\
\hline $1982-1985$ & 3,89 & 15,1 & 6,46 & $-10,9$ & 5,36 & 14,3 & 6,22 & 12,6 \\
\hline 1986-1989 & 5,59 & 43,7 & 8,55 & 32,3 & 6,71 & 25,2 & 7,35 & 18,1 \\
\hline $1990-1993$ & 6,41 & 14,7 & 7,52 & $-12,1$ & 7,47 & 11,3 & 7,84 & 6,8 \\
\hline 1994-1997 & 8,32 & 29,8 & 7,61 & 1,3 & 6,80 & $-9,0$ & 7,72 & $-1,6$ \\
\hline $1998-2001$ & 6,95 & $-16,5$ & 7,72 & 1,4 & 7,65 & 12,6 & 6,89 & $-10,7$ \\
\hline 2002-2005 & 7,26 & 4,5 & 8,73 & 13,1 & 8,89 & 16,1 & 7,78 & 12,8 \\
\hline 2006-2009 & 6,84 & $-5,8$ & 10,14 & 16,1 & 10,83 & 21,8 & 8,01 & 3,0 \\
\hline $2010-2013$ & 8,34 & 21,9 & 11,30 & 11,5 & 9,10 & $-16,0$ & 9,29 & 16,0 \\
\hline
\end{tabular}


Таким образом, на протяжении всего периода исследования РМЖ у женщин в возрасте 0-39 лет занимает ведущее место в структуре заболеваемости ЗН и требует пристального внимания медицинских учреждений, особенно при проведении скрининговых мероприятий, профилактических осмотров и прочее.

Также была изучена динамика онкоэпидемиологического процесса в группе женского населения возраста 0-39 лет на основании интервальных четырехлетних показателей (табл. 2, рис. 2). Установлено, что в доаварийный период (1970-1985) в Украине прирост показателя заболеваемости РМЖ у женщин 0-39 лет составил $38,5 \%$, а в исследуемых областях он находился в пределах от 8,7\% в Житомирской области до 71,2\% в Киевской (табл. 3). В послеаварийный период динамика заболеваемости РМЖ изучаемой когорты существенно измени- лась. В Житомирской области прирост показателя составил $43,7 \%$, в Киевской - 32,3\%, в Черниговской - 25,2\%. В целом по Украине этот показатель не превышал 18,1\%. То есть за 1986-1989 годы превышение среднеукраинской заболеваемости РМЖ зарегистрировано во всех контаминированных областях. В 19902013 годах такая особенность динамики показателя сохранилась, и прирост заболеваемости в контаминированных областях был в 1,2-2,7 раза выше среднеукраинского.

Представляет интерес изучение характера временных трендов в динамических рядах показателя заболеваемости РМЖ у женщин возрастной группы 0-39 лет в Украине и в контаминированных областях на период до 2020 года (табл. 4, рис. 4). Анализ смоделированного динамического ряда заболеваемости РМЖ у женского населения областей радиационного контроля личился более чем в 2 раза.

Таблица 3

Прирост показателей заболеваемости РМЖ женского населения Украины и областей радиационного загрязнения в возрастной группе 0-39 лет

\begin{tabular}{|c|c|c|c|c|c|c|c|c|}
\hline \multirow{2}{*}{ Интервал, годы } & \multicolumn{3}{|c|}{ Прирост показателя заболеваемости, \% } & \multicolumn{2}{|c|}{ Ежегодный прирост показателя заболеваемости, \% } \\
\cline { 2 - 9 } & $\begin{array}{c}\text { Житомир- } \\
\text { ская }\end{array}$ & Киевская & $\begin{array}{c}\text { Черни- } \\
\text { говская }\end{array}$ & Украина & $\begin{array}{c}\text { Жито- } \\
\text { мирская }\end{array}$ & Киевская & $\begin{array}{c}\text { Черни- } \\
\text { говская }\end{array}$ & Украина \\
\hline $1970-1985$ (15 лет) & 8,7 & 71,2 & 14,9 & 38,5 & 0,6 & 4,7 & 1,0 & 2,6 \\
\hline 1986 -1989 (7 лет) & 43,7 & 32,3 & 25,2 & 18,1 & 6,2 & 4,6 & 3,6 & 2,6 \\
\hline $1990-2013$ (23 года) & 30,1 & 50,3 & 21,8 & 18,4 & 1,3 & 2,2 & 0,9 & 0,8 \\
\hline $1985-2013$ (28 лет) & 114,3 & 75,0 & 69,8 & 49,3 & 4,1 & 2,7 & 2,5 & 1,8 \\
\hline
\end{tabular}

Таблица 4

Динамика наблюдаемого и ожидаемого уровня заболеваемости РМЖ в возрастной группе 0-39 лет

\begin{tabular}{|c|c|c|c|c|c|c|}
\hline \multirow[b]{2}{*}{ Год } & \multicolumn{3}{|c|}{ Неконтаминированные области } & \multicolumn{3}{|c|}{ Контаминированные области } \\
\hline & $\begin{array}{l}\text { Наблю- } \\
\text { даемая }\end{array}$ & $\begin{array}{l}\text { Ожида- } \\
\text { емая* }\end{array}$ & $\begin{array}{c}\text { Стандартная } \\
\text { ошибка* }\end{array}$ & $\begin{array}{l}\text { Наблю- } \\
\text { даемая }\end{array}$ & $\begin{array}{l}\text { Ожида- } \\
\text { емая }\end{array}$ & $\begin{array}{l}\text { Стандартная } \\
\text { ошибка* }\end{array}$ \\
\hline 1970 & 4,14 & 4,56 & 0,18 & 2,75 & 4,50 & 0,43 \\
\hline 1976 & 5,41 & 5,32 & 0,20 & 5,84 & 5,05 & 0,64 \\
\hline 1982 & 5,51 & 6,22 & 0,21 & 4,59 & 5,66 & 0,59 \\
\hline 1986 & 6,91 & 6,89 & 0,23 & 4,95 & 6,11 & 0,61 \\
\hline 1993 & 8,97 & 8,26 & 0,26 & 8,68 & 6,99 & 0,82 \\
\hline 1996 & 7,38 & 7,64 & 0,24 & 7,28 & 7,40 & 0,76 \\
\hline 2000 & 6,73 & 6,89 & 0,24 & 7,50 & 7,99 & 0,80 \\
\hline 2006 & 7,60 & 7,86 & 0,26 & 7,65 & 8,97 & 0,86 \\
\hline 2014 & 8,32 & 9,39 & 0,29 & 9,30 & 10,42 & 0,90 \\
\hline 2020 & -- & 10,55 & & -- & 11,51 & \\
\hline
\end{tabular}

Примечание: * - вычисление "Joinpoint Regression Program", версия 4.1.1.4-2015 г. свидетельствует о стойкой тенденции к увеличению показателя за 1970-2013 годы. На основе регрессионной модели (коэффициент регрессии b $=0,08 \pm 0,02 ; p<0,05)$ получен прогноз заболеваемости РМЖ до 2020 года, который может достичь величины 11,510/ $0000(p=0,05)$ при ежегодном приросте показателя 1,94\%.

Вместе с тем, в остальных областях Украины регрессионная модель динамического ряда заболеваемости РМЖ оказалась несколько иной. Так, за 1970-1993 годы темпы роста показателя были выше по сравнению с радиационнозагрязненными, а ежегодный прирост составил 2,62\% $(p=0,05)$ (коэффициент регрессии $b=0,07 \pm 0,02$; $\mathrm{p}<0,05)$. В 1993-2000 годах 
RISK OF BREAST CANCER DEVELOPMENT IN THE WOMEN OF THE YOUNGER AGE

CATEGORIES IN UKRAINE

Fedorenko Z., Hulak L. , Ryzhov A. , Horokh Ye., Sumkina O., Kutsenko L.

National Institute of Cancer, Kyiv

\section{Study of the breast cancer incidence}

in the population of Ukraine and territories exposed to the Chornobyl accident has shown a stable increase in the indices, their growth rates

in the contaminated areas were twice as large as in the whole Ukraine. Breast cancer of the female population aged 0-39 years was studied separately as the most sensitive to radiation. The breast cancer was established to be consistently in the first place in the structure of incidence of the female population both of Ukraine and the studied areas (20-24\%), i.e. the breast cancer is diagnosed in one of five women with cancer, this emphasizes a significance of the problem. Study of trend models of breast cancer in the women of 0-39 years' age group showed that in the post-accident period the increase of the incidence in the contaminated areas had reached $43.5 \%$ while in Ukraine it hadn't exceed $18.1 \%$. Those features of the dynamics of breast cancer incidence promoted a significant rapprochement of the indices, registered in Ukraine and in the oblasts of radiation control, and since 1994-1997 the level of the breast cancer incidence in the majority of the radioactively contaminated areas exceeded the average Ukrainian level.

Keywords: National Cancer Registry of Ukraine, cancer incidence, epidemiology of breast cancer. наблюдалось падение темпов роста с ежегодным приростом $-2,57 \%(p>0,05)$ (коэффициент регрессии $\mathrm{b}=-0,10 \pm 0,09$; p>0,05), а за 2000-2014 гг. ежегодный прирост заболеваемости вновь вырос до ежегодных 2,24\% $(p=0,05)$ (коэффициент регрессии $\mathrm{b}=0,05 \pm$ $0,01 ; p<0,05)$ и к 2020 году показатель может достичь $10,550 / 0000(p=0,05)$. Такая особенность трендовых моделей может быть результатом увеличения риска возникновения этой патологии под влиянием радиационного фактора.

Обсуждение и выводы. Изучение заболеваемости РМЖ населения Украины и территорий, подверженных влиянию Чернобыльской аварии, показало стабильное возрастание показателей, темпы прироста которых на контаминированных территориях были в два раза выше, чем в Украине. Отдельно изучены особенности поражения РМЖ женского населения возрастной группы 0-39 лет как наиболее чувствительной к радиационному воздействию. Установлено, что РМЖ стабильно занимает первое место в структуре заболеваемости женского населения как в Украине, так и в исследуемых областях (20$24 \%$ ), т.е. у каждой пятой заболевшей раком женщины диагностируется РМЖ, что подчеркивает значимость проблемы.

Изучение трендовых моделей РМЖ у женщин возрастной категории 0-39 лет показало, что в послеаварийный период прирост показателя заболеваемости в контаминированных областях достиг $43,5 \%$, в то время как в Украине не превышал $18,1 \%$. Эти
Рисунок 1

Динамика повозрастной заболеваемости раком молочной железы женского населения
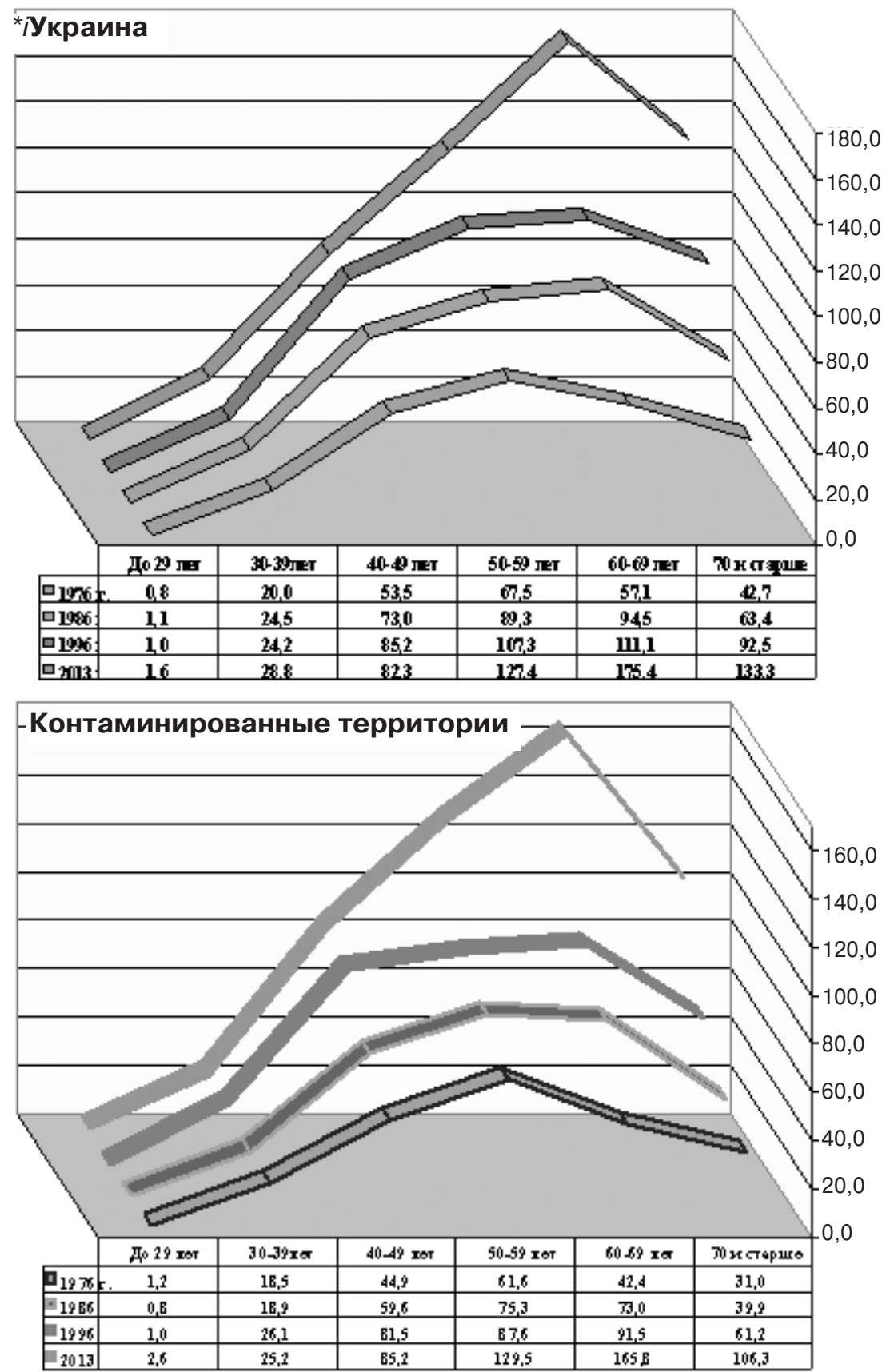
Структура заболеваемости злокачественными новообразованиями женского населения, возрастная группа 0-39 лет, \%

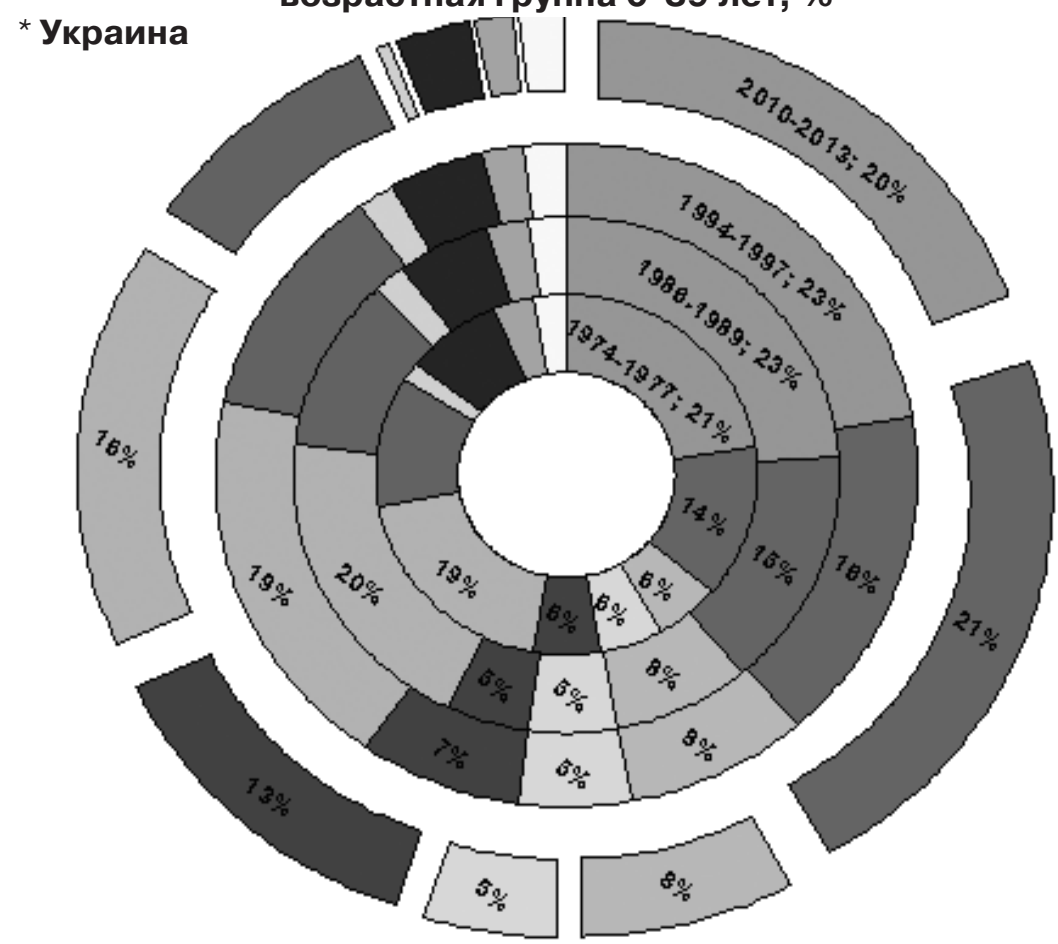

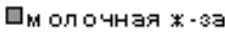
口шейка матки
口яичник
口головной м озг
Фщит овидная
口гем област озы
口кожа
口полость рта
ロжелудок
口прям ая кишка

$\square$ nerkoe

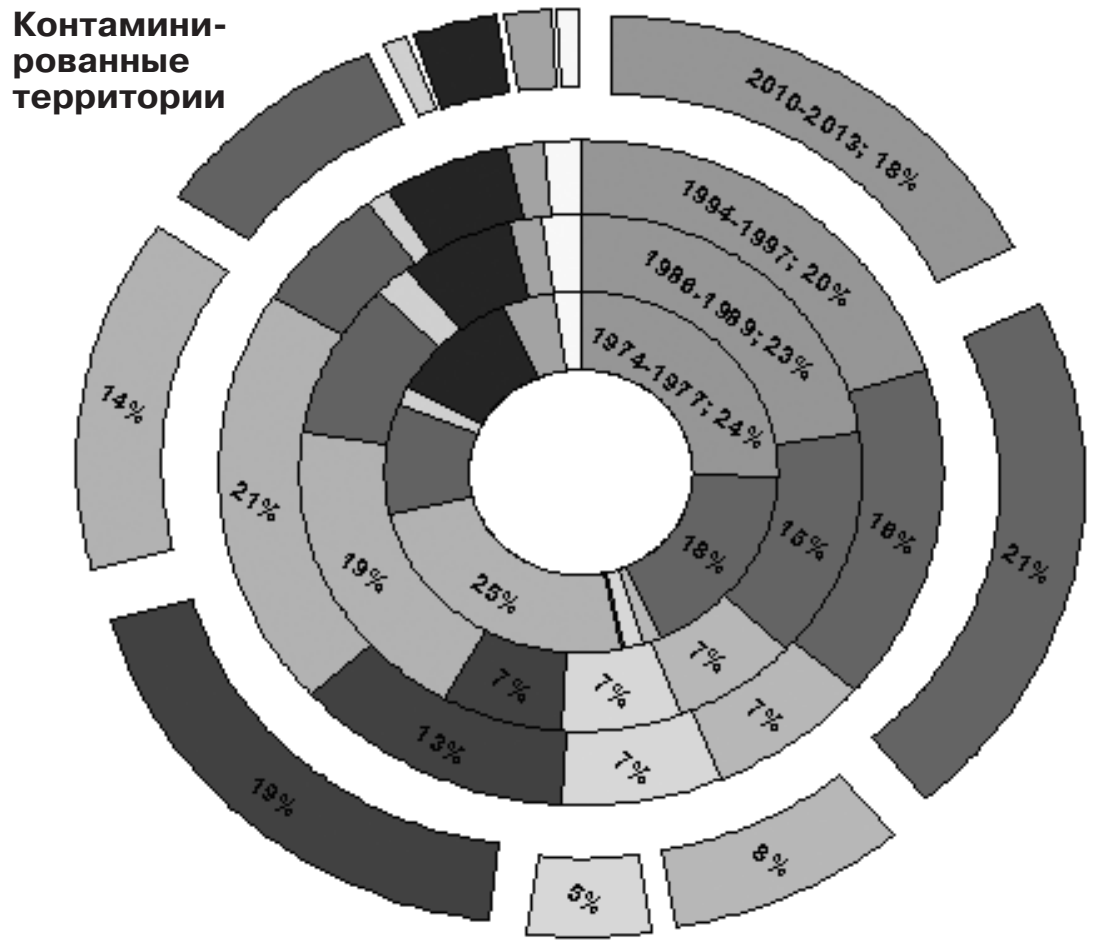

\begin{tabular}{|c|c|c|}
\hline 口молочная $x$-за & 口шейкаматки & 口яичник \\
\hline 口головной мозг & 口щитовидная $*-3 а$ & 口гмобластозы \\
\hline$\square$ кож. & 口полость рта & 口желудок \\
\hline
\end{tabular}

особенности динамики заболеваемости РМЖ способствовали существенному сближению показателей, зарегистрированных в Украине и в областях радиационного контроля, а начиная с 1994-1997 годов уровень заболеваемости РМЖ в большинстве контаминированных областей превышал среднеукраинский.

Таким образом, проведенные исследования показали, что радиационный фактор может быть одной из основных причин развития РМЖ у жительниц загрязненных радионуклидами территорий, прежде всего в младших возрастных группах. Эти результаты согласуются с данными исследований о возникновении РМЖ у жительниц Японии, подвергшихся влиянию атомной бомбардировки. Наши дальнейшие исследования с использованием возможностей Национального канцеррегистра будут направлены на оценку риска возникновения не только РМЖ, но и других локализаций ЗН у групп населения, пострадавшего от радиационного воздействия, прежде всего в детском и подростковом возрасте. Такие исследования имеют не только научное, но и практическое значение для профилактики возникновения ЗН, своевременного выявления РМЖ и ЗН других локализаций - кишечника, мочеполовой сферы, гемобластозов и прочих радиационно-обусловленных новообразований, латентный период которых может превышать 25-30 лет.

\section{ЛИТЕРАТУРА}

1. Рак в Україні, 2013-2014. Захворюваність, смертність, показники діяльності онкологічної служби / З.П. Федоренко, Ю.Й. Михайлович, Л.О. Гулак та ін. // Бюлетень Національного канцер-реєстру України. - Київ, 2015. - № 16. $-106 \mathrm{c}$.

2. Incidence of female brest cancer among atomic bombing survivors, 1950-1985 / M. Tokumaga, C. Land, S. Nokuoka et al. // Radiat. Res. - 1994. Vol. 138. - P. 209-223.

3. Shimizu Y. Risk of cancer among atomic bombing survivors /Y. Shimizu, H. Kato, W.J. Schull // J. Radiat. Res. Tokyo. - 1991. - Vol. 32, Suppl. 2. - P. 54-63. 
4. Time-trends in female breast cancer incidence in contaminated and non-contaminated areas of the Zhytomyr oblast, 1982-2000 / A.Yu. Ryzhov, L.O. Goulak, Ye.L. Gorokh, E.V. Soumkina // Abstract Book of 24-th Annual Meeting of the International Association of Cancer Registries. - Tampere, 2002. - Part 1.1. - P. 12-17.

5. Gene-radiation interactions: their influence on pre-menopausal breast cancer risk after Chornobyl. Final Technical Report IARC / L. Gulak, E. Gorokh, A. Ryzhov et al. - Lyon, 2004. 200 p.

6. Breast cancer in Belarus and Ukraine after the Chernobyl accident / E. Pukkala, A. Kesminiene, S. Poliakov et al. // Int. J. Cancer. - 2006. - V. 119. P. 651-658.

7. Захворюваність на рак молочної залози жіночого населення України до і після аварії на ЧАЕС / А.Є. Присяжнюк, В.Г. Грищенко, З.П. Федоренко та ін. // Журнал Академії медичних наук України. - 2007. - Т. 13, № 4. C. 676-687.

8. Досвід епідеміологічного вивчення раку молочної залози у зв'язку з Чорнобильською аварією / А.Є. Присяжнюк, А.Ю. Романенко, З.П. Федоренко та ін. // Здоровье женщины. - 2008. - 4. 2, Т. 36, № 3. - C. 85-91.

9. Епідеміологія раку молочної залози в Україні. Оцінка можливості чорнобильського впливу / А.Є. Присяжнюк, А.Ю. Романенко, З.П. Федоренко та ін. // Чорнобильський науковий вісник. - 2008. № 2 (32) . - C. 47-54.

10. Brest cancer / A. Prysyazhnyuk, A. Romanenko, Z. Fedorenko et al. // Health effects of the Chornobyl accident a quarter of century aftermath . - Kyiv: DIA, 2011. - P. 196204.

11. Особенности трендовых моделей заболеваемости раком грудной железы в Украине после аварии на ЧАЭС / З.П. Федоренко, Л.О. Гулак, Е.Л. Горох и др. // Клиническая онкология. - 2012. - № 5 (1). - C.11-15.

12. Чверть століття після Чорнобильської аварії: ризик раку у групах постраждалого населення / А.Є. Присяжнюк, Д.А. Базика, А.Ю. Романенко та ін. // Проблеми радіаційної медицини та радіобіології : зб. - Київ : ДІА, 2014.- Вип. 19. - С. 147-169.

13. Источники и действие ионизирующей радиации. Доклад НКДАР за 1977 г. Генеральной Ассамблее ООН. - Нью-Йорк : $\mathrm{OOH}, 1978 .-$ T. 1-3.

14. UNSCEAR 2000 Report to the General Assembly. Annex J. Exposures and effects of the Chornobyl accident // Int. J. Rad. Med., Special Issue. - 2000. Vol. 2-4, № 6-8. - P. 3-109.

15. Joinpoint Regression Program, Version 4.1.1.4 - February 2015; Statistical Methodology and Applications Branch, Surveillance Research Program, National Cancer Institute. REFERENCES

1. Fedorenko Z., Mykhailovych Yu., Gulak L., Gorokh Ye. , Ryzhov A., Sumkina O. Rak v Ukraini, 2013-2014. Zakhvoriuvanist, smertnist, pokaznyky diialnosti onkolohichnoi slushby [Cancer in Ukraine, 2013-2014. Incidence, Mortality, Activities of Oncological Service]. In : Biuleten NatsionsInoho Kantser-reiestru Ukrainy [Bulletin of National Cancer-Registry of Ukraine]. Kyiv ; 2016 ; 16 : 106 p. (in Ukrainian)

2. Tokumaga M., Land C., Nokuoka S., Nishimori I.,Soda M., Akiba S. Radiat. Res. 1994 ; 138 : 209-223.

3. Shimizu Y., Kato $H_{\text {., }}$ Schull W.J. J. Radiat. Res. Tokyo. 1991 ; 32 (2) : 54-63.

4. Ryzhov A. Yu., Goulak L. O., Gorokh Ye. L., Soumkina O.V. Time-trends in Female Breast Cancer Incidence in Contaminated and Non-contaminated Areas of Zhytomyr Oblast, 1982-2000. In : Abstract Book of 24-th Annual Meeting of the International Association of Cancer Registries. Tampere. 2002 ; 1.1 :12-17.

5. Gulak L., Gorokh E., Ryzhov A., Sumkina E. et al. Gene-radiation Interactions: their Influence on Pre-menopausal Breast Cancer Risk after Chornobyl. Final Technical Report IARC. Lyon ; 2004 : 200 p.

6. Pukkala E., Kesminiene A., Poliakov S., Ryzhov A., Drozdovitch V., Kovgan L, Kyyronen P. et al. Int. J. Cancer. $2006 ; 119$ : 651-658.

7. Prysiazhniuk A., Gryshchenko V., Fedorenko Z., Fuzik M., Gulak $L$. Journal of the Academy of
Medical Sciences of Ukraine. 2007 ;13 (4) : 676-687 (in Ukrainian).

8. Prysiazhniuk A., Romanenko A., Fedorenko Z., Fuzik M. et al. Zdorovie zhenshchiny. 2008 ; 36 (3) : 85-91 (in Ukrainian).

9. Prysiazhniuk A., Romanenko A., Fedorenko Z., Gulak L., Gorokh Ye. et al. Chornobylskyi naukovyi visnyk. 2008 ; 2 (32): 47-54 (in Ukrainian).

10. Prysiazhniuk A., Romanenko A., Fedorenko Z., Fuzik M. , Gudzenko N., Goulak L. et al. Breast Cancer. In : Health Effects of the Chornobyl Accident a Quarter of Century Aftermath . Kyiv: DIA ; 2011 : 196-204

11. Fedorenko Z., Gulak L., Ryzhov A., Gorokh Ye., Sumkina O., Kutsenko L. Klinicheskaia onkologiia. 2012 ; 5 (1) : 11-15 (in Russian).

12. Prysiazhniuk A., Bazyka D., Romanenko A., Gudzenko N., Fuzik M., Fedorenko Z. et al. Chvert stolittia pislia Chornobylskoi avarii : ryzyk raku v hrupakh postrazhdaloho naselennia [A Quarter of Century after the Chornobyl Accident: the Risk of Cancer in the Affected Population Groups]. In : Problemy radiatsiinoi medytsyny ta radiobiolohii [Problems of Radiation Medicine and Radiobiology]. Kyiv ; 2014 ; 19 : 147169 (in Ukrainian).

13. UNSCEAR Report to the General Assembly of the UN. Sources and Effects of lonizing Radiation. New York ; 1978 ; 1-3 (in Russian).

14. UNSCEAR 2000 Report to the General Assembly. Annex J. Exposures and Effects of the Chornobyl Accident. In : Int. J. Rad. Med. 2000 ; 2-4 (6-8) : 3-109.

15. Join point Regression Program, Version 4.1.1.4 - February 2015; Statistical Methodology and Applications Branch, Surveillance Research Program, National Cancer Institute.

Надійшла до редакції 14.10.2015 